\title{
THE ESSENCE OF MARINE AND COASTAL SPACE - AN INTERDISCIPLINARY PERSPECTIVE
}

\author{
Katarzyna Jerzak $^{1}$, , Maxim D. Shrayer ${ }^{2}$, Karolina A. Krośnicka ${ }^{3}{ }^{(D)}$, Piotr Lorens ${ }^{3}$, Jacek Zaucha ${ }^{4}$, \\ Joanna Pardus ${ }^{5}$ \\ ${ }^{1}$ Institute of Modern Languages, Pomeranian University in Słupsk \\ Słowiańska 8, 72-600 Słupsk: Poland \\ katarzyna.jerzak@apsl.edu.pl \\ ${ }^{2}$ Department of Slavic and Eastern Languages and Literatures, Boston College \\ Lyons Hall 210, 140 Commonwealth Avenue, Chestnut Hill MA 02467-3804: USA \\ shrayerm@bc.edu \\ ${ }^{3}$ Faculty of Architecture, Gdańsk University of Technology \\ Narutowicza 11/12, 80-233 Gdansk: Poland \\ karolina.krosnicka@pg.edu.pl•plorens@pg.edu.pl \\ ${ }^{4}$ Faculty of Economics, University of Gdańsk \\ Armii Krajowej 119, 81-824 Sopot: Poland \\ Institute for Development \\ Czyżewskiego 6/1, 81-706 Sopot: Poland \\ jacek.zaucha@ug.edu.pl \\ ${ }^{5}$ Maritime Institute in Gdańsk of Maritime University of Gdynia \\ Długi Targ 41/42 St 80-830 Gdańsk \\ Institute for Development \\ Czyżewskiego 6/1, 81-706 Sopot: Poland \\ joanna.pardus@im.umg.edu.pl
}

\begin{abstract}
Sea space has been undergoing a profound transformation. Although it retains its inspirational function in arts, literature and philosophy, it has been gaining new anthropogenic dimensions in economics and urban planning as a source of satisfying human needs i.e. the provision of harmony, beauty, off-shore energy, and biotech substances. Therefore, in this paper marine space is analyzed from a multidimensional perspective of urban planning, economics, and literature. Maritime space has been a subject of literature from its inception. Without attempting to give an overview of the vast topic, the paper discusses the pronounced presence of sea space in the earliest Western literary sources, such as the Bible and Anglo-Saxon poetry. As a striking case study, Herman Melville's 1851 novel Moby-Dick is analyzed with its complex, dynamic notion of maritime space. Aditionally, the importance of the shore as locus amoenus in a short story by the contemporary writer Maxim D. Shrayer is examined. This notion of locus amoenus is also present in the research related to urban planning. Maritime space attracts people to locate nearby. Development is created as a response to these demands. Both urban planning and economics underline, however, a need of sustainable development of this space. This is crucial in order to secure its positive influence on human well-being in the long run. The three disciplines also point out that maritime space remains in the process of continuous creation and re-development in course of adding new functional and axiological ties between humans and the seas and oceans. Thus, nowadays maritime space covers both sea and terrestrial gateways servicing the sea and the key constituting factor is provided by human beings (homo maritimus) through their economic, social or emotional bond to the sea.
\end{abstract}

Keywords: literature, locus amoenus, maritime space, spatial economics, urban planning. 
... and the spirit of God was hovering over the face of the water.

Genesis 1:2

My soul roams with the sea, the whales' Home, wandering to the widest corners of the world, returning ravenous with desire, Flying solitary, screaming, exciting me To the open ocean, breaking oaths On the curve of a wave.

"The Seafarer" tr. Burton Raffel

\section{Introduction}

As seas and oceans become increasingly developed, this very process demands a more profound examination and understanding. The increase in the economic use of sea areas is a process that has been already visible and has been described in political documents and reports (EC, 2016, p.2; OECD, 2016, p.13). There are new ways to reap the benefits of the sea (EC 2014, p.3) and the current ones change its content and importance (Zaucha, 2009b). However, the ongoing development of so-called blue economy creates also severe risks and challenges. Seas and oceans deliver not only important economic benefits but also provide human beings with aesthetic and emotional values, satisfying human needs for beauty and grandeur. For instance, biodiversity belongs to the most important human values as a such (Fig. 1). The marine ecosystem forms the larger part of the earth's ecosystem. Seas and oceans produce some crucial ecosystem services that guarantee proper functioning of our planet because they absorb nutrients and greenhouse gases, mitigate climate change and neutralize other human pressures. To understand the importance of seas and oceans for humankind, one should take into consideration various scientific perspectives. This paper fills in this gap by offering a more comprehensive framework for studying and examining the development of maritime space using the research apparatus of different scientific disciplines contributing to the approach proposed by Ehler, Zaucha and Gee (2019) or Gee (2019).

\section{Maritime/marine space ${ }^{1}$}

The category of space in social sciences has been defined and understood in different ways. Zaucha (2007, p.12-13) has compiled a long list of various meanings and roles that researchers assign to this category e.g.: space as a limited non-renewable resource, a public good, a development condition, an intrinsic value and a policy instrument enhancing its effectiveness. On top of that, space might play an important role in regional integration (e.g. formation of the Baltic Sea region with its unique macroregional strategy ${ }^{2}$ or the Alpine macroregion). Therefore space is researched by representatives of various scientific disciplines. Spatial planners are accompanied by physicists, biologists, geographers, economists, political scientists, sociologists, philosophers and representatives of other artes liberales including literature. This makes sense since space is the "object of negotiation and compromise, open to multiple interpretations" (Faludi, 2013, p.8).

\footnotetext{
${ }^{1}$ Adjectives marine and maritime in relation to space will be used interchangeably following the proposal of Zaucha and Gee (2019) although for some authors they have slightly different meanings i.e. relate marine to natural and maritime to economic processes constituting the space in question (OECD, 2016, p.21; Cormier, Kannen, Elliott, \& Hall, 2015, p.1).

${ }^{2}$ On the EU Strategy for the Baltic Sea Region please see: Zaucha, Böhme, Pyć, Neumann and Aziewicz (2020).
} 
Maritime space is part of geographical space and should be interpreted in close connection with this category. There is not, however, a single universally accepted definition of geographical space (Thrift, 2009, p. 85; Lisowski, 2014, p.8), although this issue has been the subject of analysis by many prominent researchers (Davoudi \& Strange, 2009; Merriman et al., 2012), and the traces of the debate on the subject available in literature date back to the 1950s (Sack, 1973). This is due to the multidimensional nature of this category and the interpenetration of different research paradigms in trying to define it. Space "can be recognized as absolute or relational, as real or formal, and real as objective or subjective" (Lisowski, 2014, p.8). Parysek (2007, p.31) defines this category as "a collection of geographic objects between which there are different kinds of relationships forming the material of this space". In addition Więckowski $(2010$, p.50) indicates that the socioeconomic dimension of geographical space is determined by the position of objects, distance, and the relationships between them (spatial structure, networks, hierarchies). This kind of space is generally considered in geography to be the broadest spatial category; hence within it, discrete subspaces are assigned, including the socio-economic subspace. Castells (2000, p.442-446) believes that the contemporary socio-economic space is organized around flows: capital, information, technology. From the above definition, a picture emerges of space constituted by the relations between geographic objects including both the natural environment and the anthropogenic investments.

Assuming that maritime space is part of the wider geographical space in its real terms but also in its formal and perceptive dimension, it is important to identify the relationship that constitutes maritime space as a subspace of geographical space. The main problem is the different geographical extent of those relations. They are of socio-economic (economic), natural (including

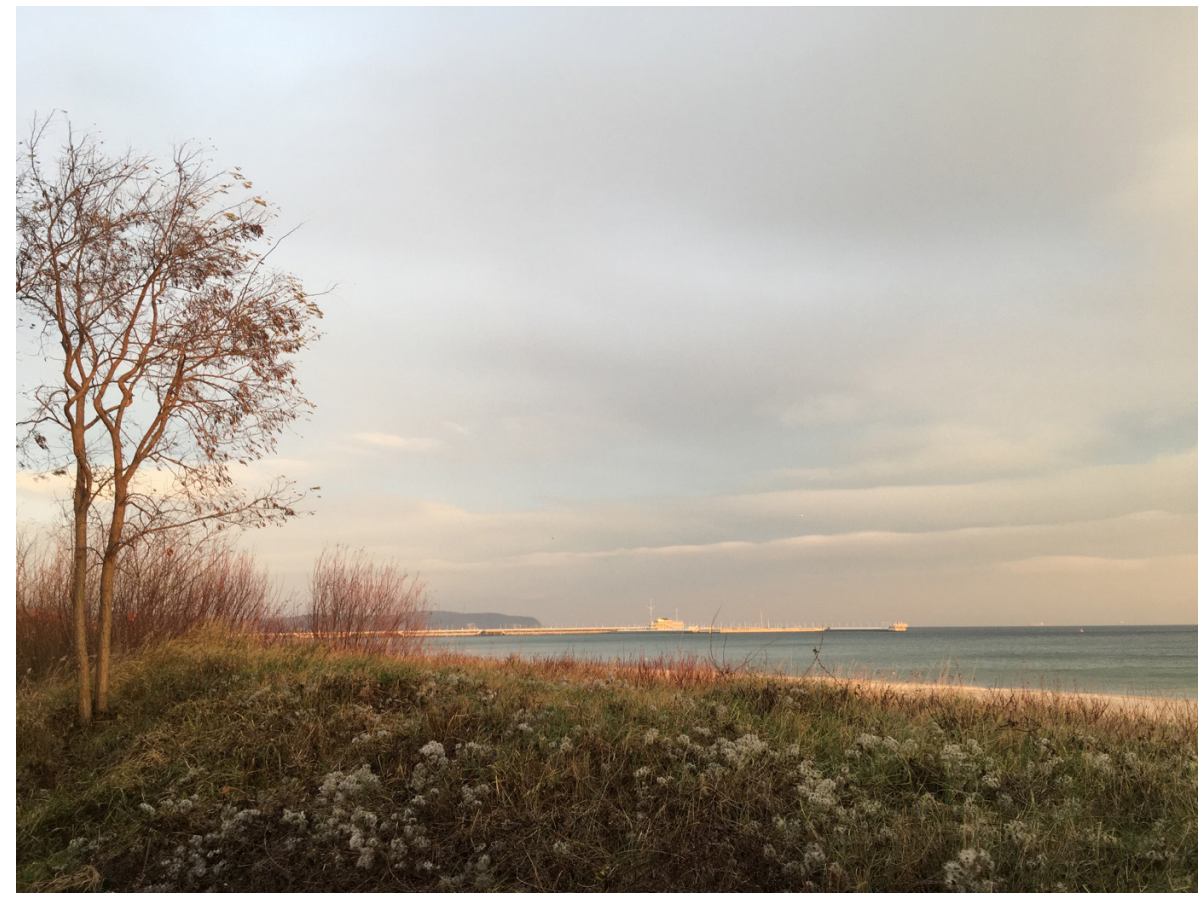

Figure 1. The Bay of Gdańsk at Sopot, Poland with a view of the Sopot Pier and the Orłowo Cliff Photo by K. Jerzak 
oceanographic in the sense of physical oceanography), behavioural (perception, symbolic issues) and administrative (regulatory) character. The above list of interactions is probably not full and exhaustive but shows the manifest difficulty. Some relationships are limited to the area of actual marine waters and possibly the shoreline (e.g. physical oceanography) while others, e.g. economic or behavioural involve land, others yet, e.g. climate processes, are global in nature. In fact, there is no single maritime space, and each of its delimitations is arbitrary. Rather, we are dealing with a number of overlapping spaces of this type, with varying scope and intensity of relations that constitute them.

There is no one uniformly agreed upon definition of maritime space. For the purpose of this paper, having in mind the aforesaid general definitions of the space, it is proposed to define maritime space by analogy with the geographical space as its part that refers directly to the natural environment of the sea, i.e. as part of the maritime surface of the earth, with its investment in their mutual spatial and temporal relations. Considering, however, the complexity of the interactions constituting maritime space, and taking into account the fact that their centre is the human being who does not live in the sea, the land "gateway points" servicing sea but located at land such as ports or harbours must also be counted as part of the maritime space. Hence the proposal is to limit marine space in its natural dimension to the marine ecosystem, and in the cultural, aesthetic and socio-economic dimension to the sea and land-based points shaping its spatial development. Thus maritime/marine space covers also the coast (Fig. 2). Any development of the "wet" part of maritime space cannot be properly explained without considering what is happening on the coast and vice versa (see Szejgiec-Kolenda,Pardus \& Zaucha, 2018).

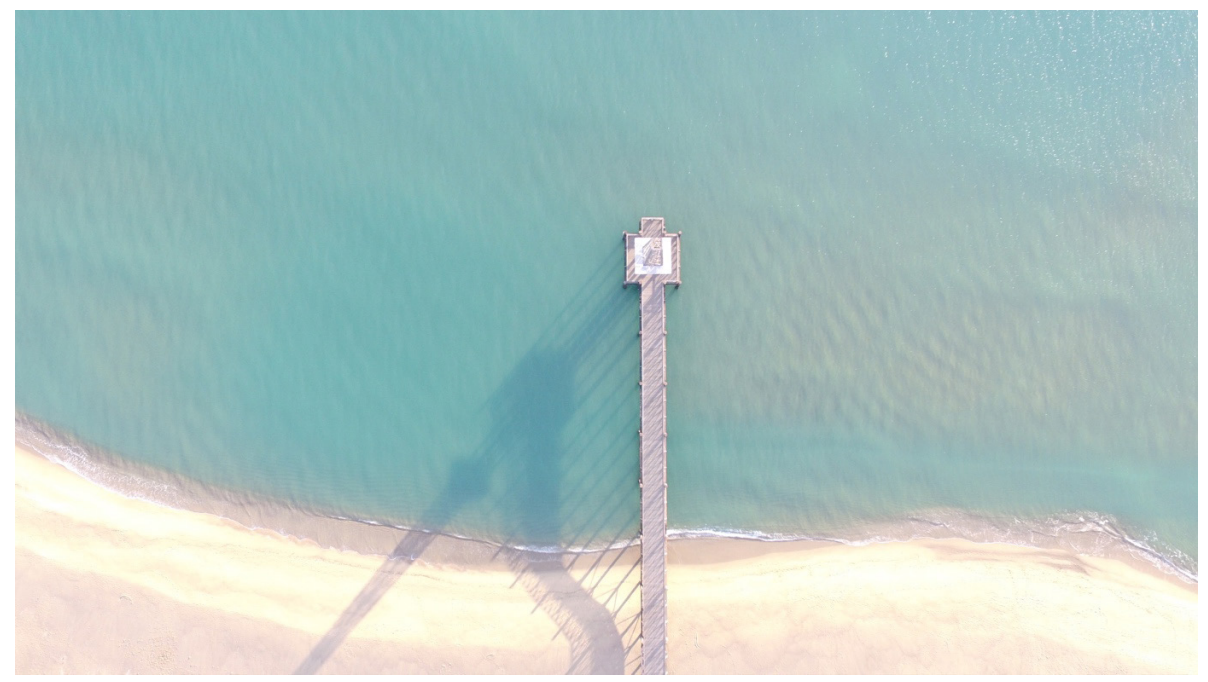

Figure 2. The pier at Leucate, France Photo by B. Jerzak 


\section{Essence of the maritime/marine space - a spatial economics perspective}

The nature and relations constituting maritime space sharply differ from its terrestrial counterpart. Differences frequently cited in the literature include (drawing on Zaucha, 2009a, p.30-31 on the basis of Tyldesley, 2004, p.10-12; Zaucha, 2018, p.10):

- the three-dimensional (or four-dimensional if time is included) nature of maritime space allowing for a greater flexibility of accommodation of various uses,

- greater importance of natural factors for functioning of the maritime space (seas and oceans as functioning ecosystems producing important ecosystem services - cf. Lillebø et al. (2016) such as climate change mitigation, tourism attractiveness, etc.),

- resultantly different dynamics of diffusion processes - e.g. a much more rapid dispersal of pollutants than on land, and an easier penetration of pollutants into marine living organisms, as well as much higher probability of transborder impacts including pressures,

- people inhabiting only land gateways of the maritime space, resulting in a lack of permanent presence of human beings in the sea areas,

- prevalence of public over private ownership, and resultantly threat of tragedy of the commons, as well as a significant limitation of the national power over the space in relation to the exclusive economic zone and high seas,

- different technologies necessary for development of maritime space i.e. greater flexibility of forming transport connections, much higher wind energy yield etc.

In addition to the above listed issues one should take into consideration the changing role of marine areas. They cease to be the areas of separation between different state and economy organisms. They lose the character of the traditional border (frontier) and become the contact point of various political, economic and environmental interests. Moreover, anthropogenic pressure on seas and oceans has been increasing rapidly as discussed in the introduction. The question is whether and to what extent maritime development is not the next step in departing from the spirit of Ratzel's geographical determinism (environment has long since ceased to determine human activities on land, but to some extent still determines them at sea), which implies a multiplicity of goals and paths of development and demands specific selection processes.

Those differences are decisive for the development of maritime space. But two issues seem of primary importance from the perspective of economics.

It seems that the first and the most important peculiarity of the development of maritime space concerns sea space ownership. Lack of residence at sea causes jurisdictional rights to apply less and less in proportion to the distance from land. In general, it is rare for maritime space to have a private owner. The exception in the Baltic is for example Sweden, in the archipelagic areas. As a rule, public ownership dominates. The framework of jurisdiction over ocean space is conferred by international law, i.e. the United Nations Convention on the Law of the Sea UNCLOS (Pyć, 2019). According to its provisions, coastal states have nearly full authority (with some exceptions that mainly affect shipping) to 12 nautical miles from the baseline (territorial waters). The following are subject to the states' jurisdiction: airspace over the territorial sea, the sea itself, as well as its bed and subsoil. Further in the exclusive economic zone - the EEZ (up to 200 nautical miles excluding seabed and subsoil and airspace above EEZ) these powers are much smaller and are limited to natural resource management, research, economic exploitation and exploration of other benefits such as wind or tide and environmental protection (Maes, 2008, p.80018002). In this zone other countries have the right to free shipping, and laying cables and pipelines, 
but in such a way as not to violate the rights of the coastal state to use its EEZ. The same is true on the continental shelf, which includes the seabed and subsoil of the submarine areas that extend beyond its territorial sea throughout the natural prolongation of its land territory to the outer edge of the continental margin, or to a distance of 200 nautical miles from the baselines from which the breadth of the territorial sea is measured where the outer edge of the continental margin does not extend up to that distance. Part of the EEZ is an contiguous zone where coastal states have the additional right to protect their cultural heritage and to prosecute crimes committed on their territory. As for the high seas(water column and airspace beyond the EEZ), as well as "the Area" (seabed, ocean floor and subsoil beyond national jurisdiction) they are considered a shared heritage of humankind managed by the International Maritime Organization (Symonides, 2012, p.12; Pyć, 2019, p.378-380). On the high seas there is freedom of navigation, over-flight, laying of cables and pipelines, constructing artificial islands or other installations, fishing and scientific research, although the last four freedoms are conditional (art. 87 of UNCLOS) (Maes, 2008, p.779). Activities related to exploitation of the Area's resources are managed by the International Seabed Authority in line with a principle of good faith and ensuring fair distribution of benefits to all states (Pyć, 2019, p.380). The absence or limitation of property rights means that maritime space is under public governance regime either national or international with all benefits but also problems related to that (e.g. Hassler et. al., 2018).

Moreover, ocean space and the resources contained in it a source of non-pecuniary externalities. There are several reasons for that. Many services associated with ecosystems are nothing but a part of public goods (influence on the climate, seascapes) (see Daly \& Farley, 2011, p.169). Externalities take form of marine pollution (negative), or nutrient absorption through aquaculture (positive). Also sea uses such as off-shore renewable energy offer quite a large number of positive (clean energy, artificial reef) and negative (noise pollution, risk of accident) externalities. Moreover, maritime space should be maintained for future generations that are not able to reveal their preference at the market when it comes to its development. All these substantiate risks for market failure and calls for public intervention in development of the maritime space. However, market failure can be accompanied by governance failure due to e.g. asymmetry of information, i.e. potential users often have more knowledge about maritime space than the actual owner. This makes the public decision process vulnerable to the capture by vested interests.

Due to the aforesaid ownership peculiarities and importance of international law in regulating the use of seas and oceans, the position of different sea users is unequal. For instance, in Poland the wind industry has to bear the cost of using the sea space which has a substantial impact on their services' prices. Other users, such as sailors or fishers, are allowed to access the sea for free. This disrupts effective development of the maritime space by using market mechanisms. Summing up, the development of maritime space has a high opportunity cost attached to it (many of those costs are external) and it may be impossible to maximize the difference between profits and costs relying solely on the market. Full picture behind development of maritime space requires examination of interrelations between market and public choice outcomes (more in Zaucha et al., 2020).

Secondly, as above indicated, ocean space is not inhabited by people. This means a separation of the place of economic benefits in the form of natural capital exploitation from the place of their formal attribution. Therefore, market forces shape maritime space differently than the terrestrial one. For instance, settlements in maritime space do not follow economic processes like the ones shaping them on land (Domański, 2016b, p.28). Consequently, the changes of the ocean economic structures are primarily caused by capital flows, but it is difficult to claim that these flows will have a significant impact on the attractiveness of a given place for the settlement purposes as it does 
in land-based flows (Domański, 2016a, p.55). They can, however, increase the attractiveness of places on land in their immediate neighbourhood, such as certain ports, tourist destinations, clusters and settlement networks. This also means different shaping of functional links than on land and the lack of many phenomena considered as determinants of the creation of functional regions (e.g. commuting to work, suburbanization, etc.). However, the most important difference is the absence of economies of agglomeration in the sea areas.

According to the World Bank (2009), the economies of agglomeration are among key decisive factors on development of terrestrial space. One of the most comprehensive attempts at an analysis of the economies of agglomeration is to be found in Fujita and Thisse (2002). The authors, referring to Adam Smith's thought, state that the "fundamental trade-off of a Spatial Economy" are the increasing returns and transportation costs (Fujita \& Thisse, 2002, p.95). Increasing returns, along with an increase in production scale, are the result of externalities stemming from proximity to other businesses, supply chain efficiency and customer perceptions, as well as more efficient (better specialized) labour resources and lower matching costs (Fujita \& Thisse, 2002, p.98). All this contributes to the economies of agglomeration that, according to McCann (2013, p.54-56), include: internal returns to scale (which require the concentration in a single place of significant capital and labour inputs), economies of localization (physical proximity of enterprises in the same sector) and economies of urbanization (proximity of enterprises of various sectors). According to the new economic geography (Krugman, 1991, p.101-113), this process is reinforced by the influx of workers, encouraged by the relatively higher wage levels in places where such benefits emerge. This in turn allows for an increase in the number of services and goods produced in a given location, which is important in the situation of consumer preferences for variety. As a result, there are processes of catastrophic concentration followed by a spatial bifurcation of the economy. However, they are countered by the costs of overcoming space resistance. When they are large, the local market does not allow for the emergence of large business entities as they would not have the sufficient market to be served by them. Production has to take place close to the consumer, and consumers do not look for employment outside of the place of residence, due to the low concentration of production in space.

Unfortunately, new economic geography cannot be applied to explain the development of maritime space (at least in the sea areas). From the entire array of elements of new economic geography only local assets (territorial capital) and the cost of transport appear also at sea. The economies of agglomeration, even if they do occur at sea (i.e. in ocean space), have very high transaction costs or barriers of nonconformity and temporal friction. This is due to maritime spatial features described above and the differences in the market power of the operators of the sea space. The development of the sea areas is rather an interplay of natural conditions (bathygraphy, availability of sea resources) and proximity to the coast where people are located (cost of transport play important role with this regard). Permanent spatial development at sea is concentrated in the coastal zone and on sea areas is limited to cables, pipelines and so-called artificial islands that are most often constructions supporting wind farms. Their occurrence is often limited by brachygraphic parameters. The development of sea space is thus of secondary character as it results from the needs arising on land (Zaucha, 2019). It is also the land-based processes that to a large extent limit or safeguard the productivity of marine ecosystems. This applies both to the real and the regulatory realm.

The discussion presented above shows that seas and oceans need quite a new approach from the perspective of economics to explain their spatial development. A comprehensive framework for studying the development of maritime space seems to be non-existent. However, there are some preliminary attempts to conceptualize and test the economic mechanisms behind 
such development (Zaucha 2019; Zaucha et al. 2020). However due to the specificity of marine space it seems obvious that seas and oceans should be developed in an interplay between market and public choice (legal acts, public incentives, policies and education efforts). This is the only way to acknowledge the non-market outcomes provided by them such as ecosystem services, attractions, wonders, inspiration, emotions, antagonistic and supportive relations or aesthetic values. The development of seas and oceans must be programmed in a very careful manner. Pure marketbased exploitation would create a risk of depleting sea recourses that belong to the class of nonor hardly renewable ones. In economics this is the well-known case of the tragedy of the commons, and one should keep in mind that sea and oceans are the perfect illustration of the common pool resources (Ostrom et al., 1994, p.7). Market regime might result in their overexploitation since nobody can be excluded from this process (Daly \& Farley 2011, p.169) and each additional user subtracts from the welfare of the existing users what is named in the literature as a property of subtractability (Berkes, Feeny, McCay \& Acheson, 1989). In such a case economic entities might prefer short term higher benefits even on expense of the stability of the resource itself (NRC, 1992). Public choice should prevent such an outcome. Otherwise the resilience (Davoudi, Zaucha \& Brooks, 2016) of the marine ecosystem might reach its limits. Perhaps an answer can also be found in collaborative economy (Jastrzębska \& Legutko-Kobus, 2017).

\section{Seaward Bound: maritime space in literature}

Maritime space has engaged human minds for ages, evoking deep emotions and inspiring the creation of outstanding artists. One of the oldest literary accounts of humanity, the Bible, in its first book refers to the sea and the life that came out of it. Thus, in the beginning was the sea. God looked at that primal maritime space and added light, divided the waters and separated the land from the sea. The foundational narrative of the Judeo-Christian tradition opens with an account of the creation of the world in which water plays a paramount role. The initial verses of Genesis describe three grand speech acts followed by their naming: "God called the dry land Earth, and the gathering of waters He called Seas. And God saw that this was good" (Genesis 1.6-1.10).

If the original cosmogonic landscape consists of undifferentiated waters, they are then divided into land and sea. This division, however, is soon disturbed: the story of the Flood is an account of dry land become sea because of torrential rains sent as divine punishment. Thanks to the instructions that allow Noah to build the Ark and navigate the swollen waters to safety, this catastrophe does not end in complete annihilation. The image of the Ark surrounded by the nearly infinite waters of the Flood is mitigated in Genesis by the precise accounting of the passage of time: the forty days and nights of the downpour, the hundred and fifty of the Ark floating. Maritime space as perceived from the Ark may appear without end or beginning, and yet Noah sends the raven and later the dove as his scouts because he knows the watery expanse must have an end. The sea space in this account is very dynamic: waters do not remain in their place; they are threatening and overwhelming. The truly apocalyptic dimension of the sea appears in the "Song of the Sea" (Exodus 5:1-18), perhaps the most dramatic biblical rendition of maritime space which recounts the crossing of the Red Sea by the Israelites leaving Egypt. The space of the sea is miraculously split so that the Israelites cross on dry land, while their pursuers are drowned. All three narratives involve the sea as a space so basic as to be archetypal, but also stress the dichotomy of land and sea. The sea emerges as the element simultaneously indispensable and hostile, potentially deadly and therefore demanding a kind of mastery. 
If the Old Testament gives us a version of the maritime space as a kind of giant arena of divine and human interaction, the Homeric epics speak to the historical struggles for domination at sea in "The lliad", and all manner of seafaring experience in "The Odyssey". Odysseus' exile is largely a maritime one and it introduces the notion of Ithaca as a lost home in the shape of an island, surrounded by sea. Maritime space as exilic space continues to be a topos in the Anglo-Saxons poetry. Two of the handful of the earliest preserved Anglo-Saxon poems, "The Wanderer" and "The Seafarer," also testify to the archetypal nature of maritime space. The speakers are both seamen who have known the severity of the open ocean - not the sunny waters of the Mediterranean, but rather the icy North Sea. The Seafarer juxtaposes the bustling life of the city with the harshness of the stormy sea where the seagulls' cries are the only accompaniment "On an ice-cold sea, whirled in sorrow, / Alone in a world blown clear of love, / Hung with icicles. The hailstorms flew. / The only sound was the roaring sea, / The freezing waves" This space is uncongenial, menacing and harsh: it is the space of exile. Thus, the long literary Western tradition stages the maritime space as a kind of antagonistic space.

The writer who makes maritime space into a modern agon is, needless to say, Herman Melville in his formidable novel "Moby Dick or the White Whale" (1851). Already in Chapter 1, "Loomings", the narrator asserts the eternal pull of the human beings towards the sea: "Posted like silent sentinels all around the town, stand thousands upon thousands of mortal men fixed in ocean reveries. Some leaning against the spiles; some seated upon the pier-heads; some looking over the bulwarks of ships from China; some high aloft in the rigging, as if striving to get a still better seaward peep." (Melville, 1961, p.21-22). The French poet St.-John Perse, working as a diplomat for the French Legation in China in 1917, wrote in a letter to Joseph Conrad that on a long trek on horseback in the Asiatic highlands, he and his horse stopped in the middle of the great arid expanse and simultaneously turned east, towards "the invisible table of the sea and the source of salt." (Perse, 1979, p.367-368). In the same letter Perse explains to Conrad that the Chinese interior, in its extraplanetary alienation, is "the most perfect imaginable simulacrum of the sea a mirror image, like the very ghost of the sea. The obsessive memory of the sea makes itself felt here." (p.367). Even in the middle of the desert then, the space of the sea exercises a powerful attraction. In the desert, where, like at sea, the French thinkers Gilles Deleuze and Felix Guattari see the smooth space (as opposed to the striated space of the fields, streets, and other areas marked by human activity), there already exists its counterpart. They hold each other in a tension. "In the expression of the faces of camel-drivers encountered in the Gobi Desert, I sometimes thought I caught a glimpse of something like a seafarer's glance. And on the approaches to the desert I have even run across nomad carts rigged with a sail as though they were at sea" (p.368).

"The Grand Armada" chapter of "Moby Dick or the White Whale" begins with a satellite-like view of the peninsula of Malacca, the southernmost border of all Asia, and then zooms in to follow the Pequod through the Straits of Sunda. The description of Captain Ahab's ship makes clear its unique position in all the seafaring world: "the circumnavigating Pequod would sweep almost all the known Sperm Whale cruising grounds of the world" (Melville, 1961, p.365). The extraordinary thing is that "in this zoned quest," Ahab touches no land (p.365). This grand design of Ahab's expedition - sweeping, limitless, without borders - has something out of proportion with human life and custom. For a ship to touch no land is not business as usual as a major part of any sailing or shipping voyage is calling at ports. Ahab's quest is boundless; his energy compared to the sun's, cosmic: "For a long time now the circus-running sun has raced within his fiery ring, and needs no sustenance but what's in himself. So Ahab" (p.365). Mixing metaphors and elements, Melville puts the fiery captain not only on an ocean, but, in a double bid, also on a ship filled with water. 
Ahab is the blazing sun on a vessel filled with an unlikely quantity of freshwater: "She has a whole lake's contents bottled in her ample hold." (p.365). Not only is this image of the Pequod as a freshwater container voyaging atop ocean waters uncanny - freshwater juxtaposed with saltwater, water on water - but the spatial containment is also a temporal hold: "She carries years' water in her." (p.365). We are asked, as readers, to contemplate the immensity of the ocean juxtaposed with the finitude of the ship - a kind of Nebensetzung - separated only by the thin but necessary border of the ship's hull, much like a nutshell. At the same time this fragile vessel is compared to the Ark, ready to face another Flood. The finite vessel braving the infinite, no land in sight.

As the Pequod follows the Grand Armada of whales swimming "in a crescentic center" (p.367), they are being followed in turn by Malay pirates. "Corresponding to the crescent in our van, we beheld another in our rear" (p.367). Melville paints a figure of striking symmetry with the Pequod as the moving center of a cipher akin to an asymmetrical chiasmus. The whales in front are compared to a city at dawn with a "thousand cheerful chimneys" (p.366), while the pursuing pirate ships behind are "rising and falling like the spouts of the whales" (p.366). Because of the constant movement, the borders are fluid. The entire system is in motion, charged with potentiality and changing at every moment. Ahab, its ever-shuttling center, pacing to and fro on the deck, beholds the monsters he is chasing and the pirates chasing him:

\begin{abstract}
And when he glanced upon the green walls of the watery defile in which the ship was then sailing, and bethought him that through that gate lay the route to his vengeance, and beheld, how that through that same gate he was now both chasing and being chased to his deadly end; and not only that, but a herd of remorseless wild pirates and inhuman atheistical devils were infernally cheering him on with their curses; - when all these conceits had passed through his brain, Ahab's brow was left gaunt and ribbed, like the black sand beach after some stormy tide has been gnawing it, without being able to drag the firm thing from its place (p. 367-368).
\end{abstract}

The shore is one of the most primal natural borders. In the above fragment, Melville compares Ahab's forehead to a beach after a storm. The storm in question is the immediate double pursuit through the Sunda Strait, but also the pursuit of the White Whale. Ahab, then, is himself a hieroglyphic of his own fate, his "deadly end" inscribed on his brow as the black sand of a gaunt shoreline. The paradox of this metaphor, however, is its placement in the text - its context: Ahab's brow as seashore is, at that very moment, passing through a defile - i.e. through the narrow strait of Sunda, and therefore is very much at sea. The gate itself marks the border between life and death. Escaped from the pirates, Ahab and the Pequod are nonetheless headed for disaster.

In the heart of "The Grand Armada" chapter lies the description of the gallied, i.e. panicked, whales. Having suddenly abandoned their military formation, the whales become "mad with consternation" (p.368). Some swim in "vast irregular circles" (p.368) while others "helplessly float[ed] like waterlogged dismantled ships on the sea" (p.368). This is a direct reversal - and another chiasmus - of the ships that look like whales a page earlier. It is at this point of the chapter that the notion of border dissolves altogether. Like a system that is dynamic on the inside but remains in equilibrium as a whole, the herd is static as a whole but in commotion internally: "Though many of the whales, as has been said, were in violent motion, yet it is to be observed that as a whole the herd neither advanced nor retreated, but collectively remained in one place" (p.369). After the "hot pursuit" comes a lull. It is then that Queequeg strikes the first whale and Ishmael's boat is dragged "like light" into the heart of the herd. As a result, they "bid adieu to circumspect life and only exist in a delirious throb" (p.369). The passage from circumspect to delirious throb signals the transition to a different mode, even a different chronotope. In the heart of the herd 
there is a heartbeat, there are mothers and nursing calves, lovemaking, life. But the mot d'ordre in "The Grand Armada" chapter is circum: circumnavigation, circus, circumspect, circumstance, circumference. One of the first words in the novel is "circulation", followed shortly by "cirumambulate" (Chapter 1, "Loomings"). Nicholas of Cusa, in his best known work De docta ignorantia ("On Learned Ignorance", 1440), gives his famous definition of an infinite deity that is the essence of a "contracted" and seemingly finite reality: "God, who is everywhere and nowhere, is its [the universe's] circumference and center" (II.12, Hopkins translation). Thus, too, in the heart of Melville's grand novel, maritime space comes to be the cipher and the promise of peace:

And thus, though surrounded by circle upon circle of consternations and affrights, did these inscrutable creatures at the centre freely and fearlessly indulge in all peaceful concernments; yea, serenely revelled in dalliance and delight. But even so, amid the tornadoed Atlantic of my being, do I myself still fore ver centrally disport in mute calm; and while ponderous planets of unwaning woe revolve around me, deep down and deep inland there I still bathe me in eternal mildness of joy (p. 373).

One could go on to discuss the specifics of maritime space in Jack London's extraordinary short story "The Seed of McCoy", in many of Joseph Conrad's novels and stories, and in Stephen Crane's gripping "Open Boat". Neither should one neglect Ernest Hemingway's depiction of the sea in "The Old Man and the Sea" and Joseph Brodsky's in "Watermark" and in his poems. But within the limited scope of the present discussion of maritime space, let us end with an evocative description of the essence of Cape Cod: the shore as experienced by the autobiographical narrator in Maxim D. Shrayer's (2017) short story "A Genius in the Attic: Secrets of a Cape Cod Dacha". This fragment will remind us of the primal importance of the shoreline, that liminal space where land and ocean meet, the archaic sacred place that in Ancient Greece was devoted to Artemis, the goddess of borders:

But there were also the daily gifts of salt and sea. A coverlet of fog would burn off by mid-morning, but not before lapping against your face and cleansing the overnight worries. There was the Fish Pier, where seals stopped in for a plate of fish guts and a glass of briny beer. The vanishing sandbar opposite Lighthouse Beach, on which hurricanes took out their rage ... And the numerous swimming and fishing options, from the cold oceanfront beaches and the warm beaches of the Nantucket Sound to the kettle ponds-those gaping mouths of glacial joy. We were hooked, hooked on Chatham.

To conclude this subchapter on the place of the marine space in human existence through the lens of literature, one should confront what was said above with one's own perception of the role and importance of the sea. When one stands on the beach in Sopot, be it in summer when it is filled with a crowd of sunbathers, or in winter when people stroll bent in half in the cold wind, the primordial nature of the shore and the sea is clear: every single human figure arrives, halts briefly at the entrance to the beach, by the dunes, takes in the miraculous, almost cosmic opening of the world ahead of them, and then irresistibly, moves towards the water, to the very edge of it. Maritime space is the sine qua non of our human existence: it is the quintessential other in which we can seek our own reflection and against which we can define ourselves. Dangerous, sometimes deadly, it remains the source of attraction and wonder, it calls our names. As Charles Baudelaire (1857), the great modern poet of the city, once wrote, "Homme libre, toujours tu chériras la mer! (Free man, you will always cherish the sea!)".

A similar type of emotional attachment to the sea combined with the recognition of its historic importance can been seen in the short essay by the contemporary translingual author Maxim D. Shrayer which serves as an illustration of the role of the sea in bringing a peaceful atmosphere to a Tel Aviv threatened by rocket strikes (Fig. 3). 


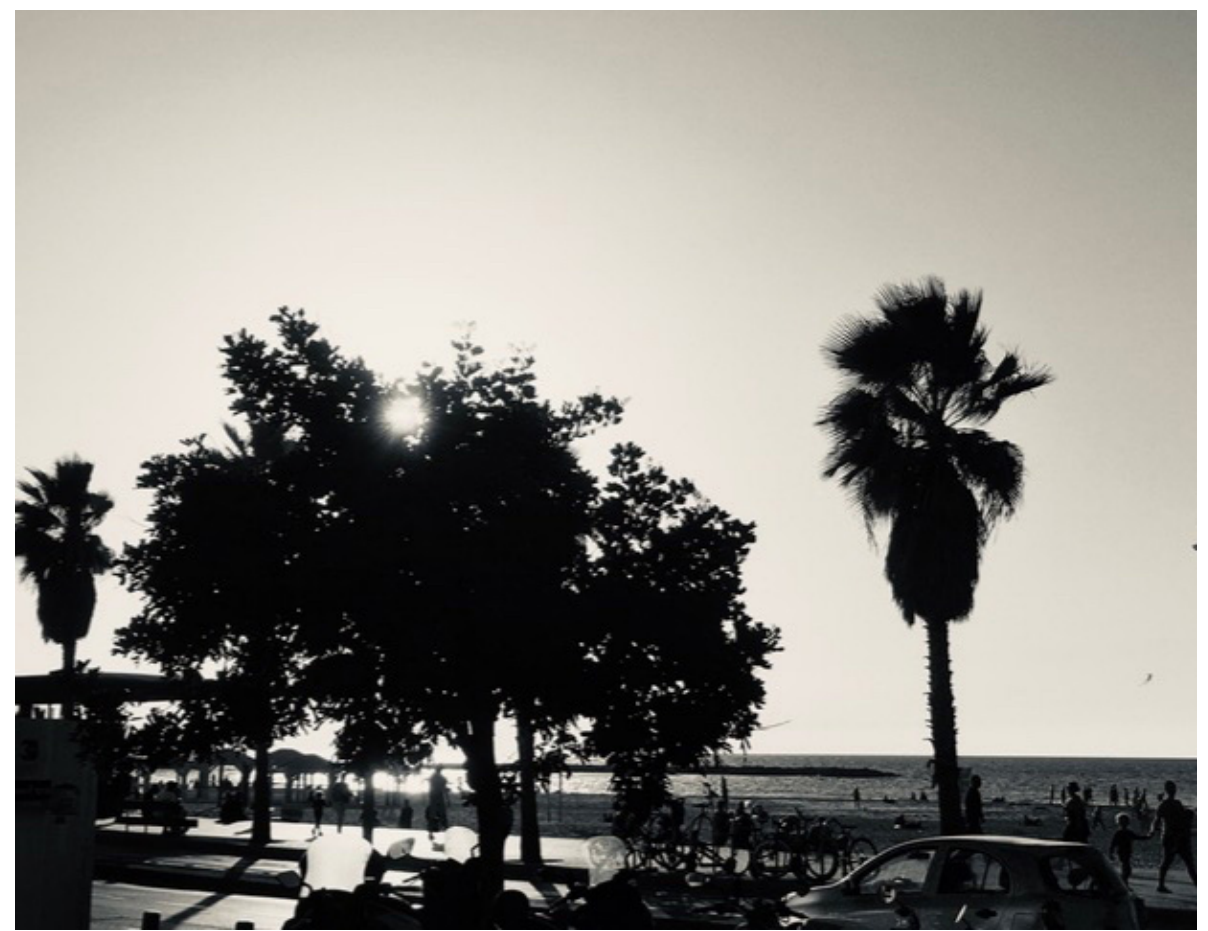

Figure 3. Tel Aviv waterfront Photo by M. D. Shrayer

On the Tel Aviv Waterfront by Maxim D. Shrayer

In the last days of November 2019 I stayed in Tel Aviv just two blocks from the sea. I had chosen my hotel based on location, Ness Tsiyona Street, a short stretch of tired apartment buildings and refurbished hotels between Ben Yehuda Street and HaYarkon Street. Artists and writers once lived in this street. The Biblical name of my hotel, Gilgal, referred to a place where Israelites stopped and pitched their tents after crossing the Jordan River. In the hotel, prophets and Teutonic tourists kept company. On my first morning I took breakfast on a rooftoop terrace with a view of the sapphire sea, now partly obstructed by glass-clad highrises going up on the waterfront and auguring the fall of old Tel Aviv - the city that remembers the giddy footsteps of my parents' uncles and aunts who had come here as young Socialist Zionists in the early 1920 s.

I cut across to the beach on Trumpeldor Street, thinking of the last words of the one-armed Jewish hero of Port-Arthur, who died defending a Jewish settlement in the Upper Galilee. Did the dying Trumpeldor mutter a tongue-twisting Russian damnation to the enemies of Israel or a Horace-infused line in broken Hebrew? It's sweet to die for one's country... It was Saturday morning on the Tel Aviv waterfront. I rented a beach chair and umbrella from a Russian man who spoke no English and practiced strong gestural Hebrew. Another Russian man, a tall tanned idler in skimpy swimming trunks, asked me if I was from "Ukraine or something", and was amused to learn that I was from Moscow by way of thirty-three 
years in New England. He claimed to know the neighborhood where I grew up - and where the Soviet atomic bomb had been developed. He told me that he went swimming every morning and that life in Israel was "a piece of cake".

All around me, strands of Russian and French speech interwove with Hebrew, forming a trilingual braid of Tel Aviv locals, tourists and potential Jewish repatriates like myself. A short distance from where I was lying out, a colorful group of Israeli women without men played music on a boombox and took turns belly-dancing and cheering. It was a happy place, an unthreatening place. Just a few days prior to my visit rockets of hate and despair had been flying from Gaza and falling on Israel. There was even one day when schools were closed in Tel Aviv. And yet the morning was so peaceful and serene that it seemed that nothing would ever harm this young city, this ancient sea, and these people basking in the sun like prodigal children of the Levant.

\section{The Essence of maritime/marine space - an urban planners' perspective}

\section{Perception of maritime space by urban planners}

Human beings are an extremely expansive species. As land areas are more and more populated, developed and expensive, and as people achieve higher and higher technological possibilities, we are entering the water areas with our investments. This contemporary process in a way resembles the era of conquering America's Wild West: schools of fish, like previously herds of bison, are substantially reduced in number; coastal fishermen, almost like Native Americans, are slowly pushed out by more economically effective industrial fishing; seabed mining activities transform the natural ecosystem of the sea; waterways and lines of energetic infrastructure cut the water space into fragments, as the railway lines did in the past, and coastal activities connected with housing and tourism are constantly developing towards the natural water areas. There are more and more various stakeholders occurring on, in and above the seawaters. The new network of human activities on the sea is crystallising now, as previously the settlement system emerged on land.

Of course this is a very distant analogy, as nowadays we are far more aware of the consequences of anthropopressure, and we have already elaborated much research and many regulations at international and national levels, which refer to the mentioned problems, trying to protect the marine ecosystem (Hassler, et al., 2019) and maritime heritage (Bender, 2015; Papageorgiou, 2018). But what is important is the fact that we cannot treat the seas as aqua incognita any longer.

The seas are still our common good, also in the sense of property (according to international agreements we have global and national rights to the seas). However, the increasing expansion of different stakeholders on the seas causes the pressure to divide property and leads to ownership fragmentation. This situation might significantly hamper an effective maritime sea planning (MSP) and also integrated coastal zone management, both of which aims to achieve sustainable blue growth.

Each scientific and professional environment has its own specificity and originates from other areas of knowledge, emphasizing different aspects of development and following a slightly different hierarchy of aims and values (e.g. biologists - welfare of living organisms, architects - functionality and form of the erected object and comfort of their user). MSP was created to prevent potential 
functional, ecological and social conflicts, but also to manage common resources in a rational way based on a system of values common for different research backgrounds and professional environments.

The area of interest of architects and urban planners are, among others, constructions erected at the interface between sea and land and at sea. This applies to both objects permanently connected with the ground, and more and more often to floating and submerged objects (especially in relation to adaptation to climate change and the rise of water level). From the point of view of an urban planner one of the most complex assemblies built at the border between sea and coasts are ports, industrial zones, energy facilities and facilities related to mining activities. Many of them tend to develop on sea waters. Therefore, planning decisions need to be taken with even higher care of environmental consequences than in case of land planning. MSP, although being a relatively novel process, offers already a large variety of tools, experiences, projects and procedures (Zaucha, 2014; Ansong, Calado \& Gilliland, 2019) which could enrich the land planning system or even transform it, offering a new insight and system of values.

\section{Harbor cities, seaports and urban waterfronts}

As discussed in the previous parts of this article, "gateway points" servicing sea but located at land such as ports or harbors must also be counted as part of maritime space. Having this in mind, any discussion of the "land side" of maritime space must take into account the entire variety of water-related spaces. These include both port structures and harbors still in use, historic (already disused) ports and maritime industry-related spaces as well as entire harbor cities (which often developed only because of the port functions located within their structures). In addition, when discussing the issues in shaping and transforming these areas, one has to take into account not only the economic, political and environmental matters but also social, architectural and urban design-related factors. In fact, when speaking about these areas, the latter ones seem to be even more important than the ones associated with the traditionally understood marine spaces. This was well phrased by L. Kołakowski (1997):

We all know that big ports are more than trade and sailing centres because they play a particular role in our culture. Our civilisation derived greatly from the Mediterranean ports. It was these ports which constituted its core: the modes of rational thinking, democracy principles and the rule of law (p.14).

Indeed, areas situated on the water have been a natural place of human settlement; at present, almost half of the world population lives on shores. Human settlements, often located on natural shores of seas, rivers and lakes, have not only profited from such neighborhood but influenced it to a large extent (Hudson, 1996). In case of cities, towns and settlements on the sea, their location has been linked to the economic use of it. Gradually, along with the development of fishery and trade, these hamlets have been adapting to more advanced roles: commercial ship harbors and shipyards have appeared there. Often these locations have been the outposts for deep seafarers and corsair or navy bases. With time, these sea settlements have become summertime resorts, attracting inlanders by their attractive climate and land- and seascapes (Zaremba, 1962). Developing port cities have increasingly become the most important elements of the world economy, parallel to the development of international trade, colonial conquest and industrial revolution. They have become the centres for cultural exchange, symbolising also the links 
between the areas of different history and experience and being the venues for the integration of a given region (the backup of a port city) with the rest of the world civilization (Hoyle, 1998). This exceptional position of port cities has been caused by, among others, the dominance of water and sea transport in the world trade which had only been reduced after the invention of the railway. This also resulted in the architecture and urban design of these cities: the relations with the sea and maritime economy can be spotted in a number of scales and types of structures, and - as a result - the entire typology of the maritime-related physical structures can be defined.

Of course, the role of port and harbor cities has been changing over decades and centuries, as a result of the changes in maritime transportation technology. But, despite these changes, ports and harbor cities still play a key role in global economy. In addition to their traditional functions, within their structures the new type of uses are developed - the so-called waterfront-related urban program (Lorens, 2013). This is associated with "living and working on the water" in a new sense, which means that people more than ever prefer to stay in visual contact with bodies of water including old harbors, disused basins, etc. As a result, the global phenomenon of the "waterfront redevelopment" has emerged, which takes various forms and shapes, including the reconstruction of historic landscapes (Lorens, Grodnicki, Osicki, Tkaczuk \& Tyślewicz, 2018).

The history of the development of port cities is inseparable from the technological evolution of sea transport, including the methods for goods reloading and their processing. This evolution has had a great influence over the shape, development and, finally, the degradation of waterfronts in cities, including old and present port structures (Hall, 1993). The changes in the interrelation between port and urban structures can be described in different ways; a model study of the issue, widely accepted and quoted in literature, was prepared by B. Hoyle (1998). Currently, the studies concerning the future of harbor cities and their spatial shape are defined, among others, by $\mathrm{C}$. Hein (2011). These studies tend to include also the new factors influencing the changing landscape of port cities: environmental and socio-economic challenges of the near future.

As a result, the perspective of maritime planning - although predominantly focusing on marine space per se - has to include also the "land side" and structures associated with water-related economy and environment. Among others, the key parts of these are harbors and port cities and their key water-related areas.

\section{Conclusions}

Different disciplines perceive the sea space differently. However, it seems that they complement each other. Economists underline such features as productivity, ability to generate benefits, the renewable or non-renewable character of those benefits, the resilience of productive systems recognizing that seas produce important goods and services both in conjunction with physical capital but also without it (with no human contribution). For spatial economists an important question is where development at sea will take place. For public economics a key concern is how to use the sea space to ensure the best satisfaction of human needs, those revealed through the market and those revealed outside the market and directly satisfied by access to the sea space that is not restricted by the need to pay for it. For economists, maritime space is an important playing ground in which economic processes take place. Those processes change this space and by doing so they close a feedback lope influencing possibilities of the space to produce goods and services and initiate new ways of changes. 
Experts in language and literature put focus on the inspirational character of maritime space. They dwell on creation, attractions, wonders, emotions, and identity with a place. For them the interplay between marine space and human beings is a key factor for framing their research. They delve to the very essence of human existence while trying to understand why people are pushed to the sea and what they find there. And finally, architects and urban planners look in particular for harmony at the land/sea interface. Their key research domains are related to functionality, conflict mitigation and respect for the ecosystem.

The above mentioned disciplines differ in their time horizon of conducted analyses of development of maritime space. Economists are confident while examining short run processes while the perspective of spatial planners is much longer. They perceive a development of maritime space as a longue durée process with important but hardly reversible consequences. They appeal to a vast array of human values and objectives. But the experts in literature operate within an even longer time horizon. They look into eternity, analysing the most important problems of human existence.

What unites all three perspectives is, surprisingly, the anthropogenic character of their research. This means that in all three: economics, spatial planning and literature, maritime space is created by human beings and their activities, while values and perceptions are of key importance for understanding the mechanisms of maritime spatial development. If we accept the idea presented at the begging of this chapter that maritime space is constituted by socio-economic, natural, behavioural, and administrative relations, the majority of which are human erected, we should acknowledge human beings as a constituting factor for developing maritime space, that continuously redefine and reengineer that space, its content and dynamics. This does not mean that natural processes are non-important for maritime spatial development. Just the opposite. In extreme cases they can jeopardize all human goals and ambitions (e.g. climate change or a tsunami can have farreaching consequences, etc.). But one should keep in mind that spatial development (development of maritime space) has a strong value-judgment or axiological component to differentiate between positive and negative character of various changes. This component is provided by a human factor and all three disciplines reflect on it as a departure point of their investigations.

\section{Acknowledgement}

The analyses presented in this paper have been financed by the Polish National Science Centre under the project "Economy of maritime space" decision no. 2015/17/B/HS4/00918.

\section{References}

Ansong, J., Calado, H., \& Gilliland, P.M. (2019). A multifaceted approach to building capacity for marine/ maritime spatial planning based on European experience. Marine Policy. https://doi.org/10.1016/j. marpol.2019.01.011

Baudelaire, C. (1857). L'homme et la mer. Retrieved from https://fleursdumal.org/poem/113

Bender, J. (2015). Conceptual development of the trail methodology for the preservation of intangible maritime heritage: A case for the Adriatic coast and islands. Journal of Marine and Island Cultures, 4(2), 55-64. https://doi.org/10.1016/j.imic.2015.09.001

Berkes, F., Feeny, D., McCay, B., \& Acheson, J.M. (1989). The benefits of the commons. Nature, 340, 91-93.

Castells, M. (2000). The Rise of the Network Society: The Information Age: Economy, Society, and Culture, 
Volume I. Oxford: Blackwell Publishers. Retrieved from http://fields.eca.ac.uk/disruptivetechnologies/wp-content/uploads/2011/10/Castells-Manuel-The-Space-of-Flows.pdf

Cormier, R., Kannen, A., Elliott, M., \& Hall, P. (2015). Marine Spatial Planning Quality Management System. ICES Cooperative Research Report 327.

Daly, H.E., \& Farley, J. (2011). Ecological economics: principles and applications. Washington, Covelo, London: Island Press.

Davoudi, S., \& Strange, I. (2009). Space and place in twentieth-century planning: an analytical ramework and an historical review. In S., Davoudi, \& I., Strange I. (Eds.). Conceptions of Space and Place in Strategic Spatial Planning (pp. 7-42). London-New York: Routledge.

Davoudi, S., Zaucha, J., \& Brooks, E. (2016). Evolutionary resilience and complex lagoon systems. Integrated Environmental Assessment and Management, 12(4), 711-718. https://doi.org/10.1002/ ieam.1823

Domański, R. (2016a). Development code of a regional economic system. An empirical test of Dendrino`s hypothesis. In W.M., Gaczek (Ed.). Gospodarka przestrzenna. Udział poznańskiego Uniwersytetu Ekonomicznego w kształtowaniu współczesnego paradygmatu (vol. 1, pp. 45-60). Poznań: Bogucki Wydawnictwo Naukowe.

Domański, R. (2016b). Self-organization in dynamic settlement system. In W.M., Gaczek (Ed.) Gospodarka przestrzenna. Udział poznańskiego Uniwersytetu Ekonomicznego w kształtowaniu współczesnego paradygmatu (vol. 1, pp. 27-44). Poznań: Bogucki Wydawnictwo Naukowe.

EC (2014). A Sustainable Blue Growth Agenda for the Baltic Sea Region. Commission Staff Working Document, Brussels, 16.5.2014 SWD(2014) 167 final.

EC (2016). International ocean governance: an agenda for the future of our oceans. Communication from the Commission to the European Parliament, the Council, the European Economic and Social Committee and the Committee of the Region. Brussels, 10.11.2016, JOIN(2016) 49 final.

Ehler, C., Zaucha, J., \& Gee, K. (2019). Maritime Spatial Planning at the interface of research and practice. In J., Zaucha \& K., Gee (Eds.). Maritime Spatial Planning, Past, Present, Future (pp. 1-21). London, Cham: Palgrave.

Faludi, A. (2013). Territory: An Unknown Quantity in Debates on Territorial Cohesion. European Journal of Spatial Development, Refereed Article No. 51.

Fujita, M., \& Thisse, J.F. (2002). Economics of Agglomeration, Cities, Industrial Location, and Regional Growth. Cambridge: Cambridge University Press.

Gee, K. (2019). The Ocean Perspective. In J., Zaucha \& K., Gee (Eds.). Maritime Spatial Planning, Past, Present, Future (pp. 23-45). London, Cham: Palgrave Macmillan.

Hall, P. (1993). Waterfronts: A New Urban Frontier. In R., Bruttomesso (Ed.). Waterfronts. A New Frontier for Cities on Water (pp. 12-20). Venice: Centro Internazionale Citta D'Acqua.

Hassler, B., Blažauskas, N., Gee, K., Luttmann, A., Morf, A., Piwowarczyk, J., Saunders, F., Stalmokaitè, I., Strand, H., \& Zaucha, J. (2019). New generation EU directives, sustainability, and the role of transnational coordination in Baltic Sea maritime spatial planning. Ocean \& Coastal Management, 169(1), 254-263. https://doi.org/10.1016/j.ocecoaman.2018.12.025

Hein, C. (2011). Port Cities. Dynamic Landscapes and Global Networks. London-New York: Routledge.

Hoyle, B. (1998). Cities and Ports: Development Dynamics at the Port-City Interface. In R., Bruttomesso (Ed.). Land-Water Intermodal Terminals. Venice: Marsilio.

Hudson, B. (1996). Cities on the Shore. The Urban Littoral Frontier. London: Pinter.

Jastrzębska, E., \& Legutko-Kobus, P. (2017). Ekonomia współpracy - definicje, klasyfikacje i dobre praktyki. Zarzqdzanie Publiczne, 4(40), 443-446.

Kołakowski, L. (1997, October 23). Pochwała kosmopolityzmu. Gazeta Wyborcza, 248, p.14.

Krugman, P. (1991). Geography and Trade. Leuven-London-Cambridge, MA: MIT Press, Leuven University Press.

Lilleb $\varnothing$, A.I., Somma, F., Norén, K., Gonçalves, J., Alves, M.F., Ballarini, E., Bentes, L., Bielecka, M., Chubarenko, B.V., Heise, S., Khokhlov, V., Klaoudatos, D., Lloret, J., Margonski, P., Marín, A., Matczak, M., Oen, A.M., Palmieri, M.G., Przedrzymirska, J., Różyński, G., Sousa, A.I., Sousa, L.P., Tuchkovenko, Y., \& Zaucha, J. (2016). Assessment of marine ecosystem services indicators: Experiences and lessons 
learned from 14 European case studies. Integrated Environmental Assessment and Management, 12(4), 726-734. https://doi.org/10.1002/ieam.1782

Lisowski, A. (2014). Typy przestrzeni a geografia. Prace Komisji Krajobrazu Kulturowego, 24, 7-18.

Lorens, P. (2013). Obszary poportowe. Problemy rewitalizacji. Szczecin: Instytut Studiów Regionalnych.

Lorens, P., Grodnicki, R., Osicki, J., Tkaczuk, J., \& Tyślewicz, D. (2018). Przekształcenia frontu wodnego Gdańska. Studia KPZK PAN, CLXXXVIII, 182-212.

Maes, F. (2008). The international legal framework for marine spatial planning. Marine Policy, 32, 797810. https://doi.org/10.1016/j.marpol.2008.03.013

McCann, P. (2013). Modern Urban and Regional Economics. Oxford: Oxford University Press.

Melville, H. (1961). Moby Dick or the White Whale. New York and Scarborough: Signet.

Merriman, P., Jones, M., Olsson, G., Sheppard, E., Thrift, N., Tuan, Y.-F., (2012). Space and spatiality in theory. Dialogues in Human Geography, 2, 3-22. https://doi.org/10.1177/2043820611434864

NRC (1992). Conserving Biodiversity. A Research Agenda for Development Agencies. Washington (DC): National Academies Press. Retrieved from https://www.ncbi.nlm.nih.gov/books/NBK234657/

OECD (2016). The Ocean Economy in 2030. Paris: OECD Publishing.

Ostrom, E., Gardner, R., Walker, J., Agrawal, A., Bloomquist, W., Schlager, E., Yan Tang, S. (1994). Rules, Games and Common-Pool Resources. Ann Arbor: University of Michigan Press.

Papageorgiou, M., (2018). Underwater cultural heritage facing maritime spatial planning: Legislative and technical issues. Ocean \& Coastal Management, 165(1), 195-202. https://doi.org/10.1016/j. ocecoaman.2018.08.032

Parysek, J. (2007). Wprowadzenie do gospodarki przestrzennej. Wybrane aspekty praktyczne. Poznań: Wydawnictwo Naukowe UAM.

Perse, St.-J. (1979). Letters. Princeton, NJ: Princeton University Press.

Pyć, D. (2019). The Role of the Sea in Marine Spatial Planning. In J., Zaucha \& K., Gee, (Eds.). Maritime Spatial Planning, Past, Present, Future (pp. 375-395). London, Cham: Palgrave Macmillan.

Sack, R.D. (1973). A Concept of Physical Space in Geography. Geographical Analysis, 5(1), 16-34.

Shrayer, M.D. (2017, April 22). A Genius in the Attic: Secrets of a Cape Cod Dacha. Tablet Magazine. Retrieved from https://www.tabletmag.com/jewish-arts-and-culture/190383/a-genius-in-the-attic

Symonides, J. (2012). Konwencja Narodów Zjednoczonych o prawie morza - w 30 lat od jej przyjęcia. Prawo Morskie, XXVIII, 7-32.

Szejgiec-Kolenda, B., Pardus, J., \& Zaucha, J. (2018). Defining maritime space typology based on economic land-sea interaction. The case of the Polish Baltic Sea coast. Bulletin of the Maritime Institute in Gdańsk, 33(1), 207-217. https://doi.org/10.5604/01.3001.0012.8173

Thrift, N. (2009). Space: the fundamental stuff of geography. In N.J., Clifford, S.L., Holloway, S.P., Rice \& G., Valentine (Eds.). Key concepts in geography (pp. 85-96). London: Sage.

Tyldesley, D. (2004). Coastal and Marine Spatial Planning Framework for the Irish Sea Pilot Project. London: Defra. Retrieved from http://jncc.defra.gov.uk/pdf/Tyldesley\%20Marine\%20spatial\%20planning.pdf

Więckowski, M. (2010). Turystyka na obszarach przygranicznych Polski. Prace Geograficzne, 224, Warszawa: IGiPZ PAN.

World Bank (2009). Reshaping Economic Geography. Washington DC: World Bank.

Zaremba, P. (1962). Urbanistyka miast portowych. Szczecin: Szczecińskie Towarzystwo Naukowe.

Zaucha, J. (2007). Rola przestrzeni w ksztattowaniu relacji gospodarczych. Ekonomiczne fundamenty planowania przestrzennego w Europie Bałtyckiej. Gdańsk: Uniwersytet Gdański.

Zaucha, J. (2009a). Planowanie przestrzenne obszarów morskich. Polskie uwarunkowania i plan pilotażowy. Gdańsk: Instytut Morski w Gdańsku.

Zaucha, J. (2009b). The Marine Economy in the Face of New Development Trends (Spatial Aspects). In T., Markowski (Ed.). The Polish Spatial Development Concept versus European Vision of Spatial Development perspectives (pp. 134-156). Warsaw: Polish Academy of Science, Committee for Spatial Economy and Regional Planning.

Zaucha, J. (2014). Sea basin maritime spatial planning: A case study of the Baltic Sea region and Poland. Marine Policy, 50, Part A, 34-45. https://doi.org/10.1016/j.marpol.2014.05.003

Zaucha, J. (2018). Gospodarowanie przestrzeniq morskq. Warszawa: Sedno. 
Zaucha, J. (2019). Can Classical Location Theory Apply to Sea Space? In J., Zaucha \& K., Gee, (Eds.). Maritime Spatial Planning, Past, Present, Future (pp. 97-119). London, Cham: Palgrave Macmillan.

Zaucha, J., Böhme, K., Pyć, D., Neumann, L., \& Aziewicz, D. (2020). EU macro-regional strategies for the Baltic Sea Region after 2020. A nutshell of beauty and possibilities. Europa XXI, 38, pp. 26. First online, https://doi.org/10.7163/Eu21.2020.38.1

Zaucha, J., \& Gee K. (Eds.) (2019). Maritime Spatial Planning, Past, Present, Future. London, Cham: Palgrave Macmillan.

Zaucha, J., Matczak, M., Witkowska, J., Szczęch, A., Mytlewski, A., \& Pardus, J. (2020). Maritime spatial rent for modelling maritime spatial development. Studia Regionalne i Lokalne, 1, (in print). 
